\title{
The Impact of Direct Feedback on Students' EFL Writing Skill: A Case Study on Writing III Course in STKIP Suar Bangli
}

\author{
Dharma, I Putu Suyoga \\ English Education Department of STKIP Suar Bangli \\ suyogadharma@gmail.com \\ Tari, Nirmala \\ Food and Beverage Product Department of MAPINDO Community Academy
}

\begin{abstract}
This case study research aims at knowing the impact of direct feedback on EFL students' writing skill. This research was done on the fourth semester students of English Education Department in STKIP Suar Bangli. Totally, there were three students selected to be the subject. The students were assigned to write short essay consisting of 6-7 paragraphs, then it was returned after direct feedback was given. Next, the students were assigned to write the new one. It was then analyzed qualitatively. Based on the result of data analysis, it was discovered that there was no significant impact of direct feedback on students' writing quality. The students still made the same mistakes as before. It implies that the use of direct feedback should be reduced in writing.
\end{abstract}

Keywords: Direct feedback, EFL, Writing skill

\section{Introduction}

Writing is productive language skills in which the students have to produce certain writing product such as short functional text and genres (Boric, 2007). Through this skill, the students have to be able to transform ideas into writing form. Here, ideas and linguistics quality determines the writing quality. For example, if the writer has good writing idea but it is not written in good language, the reader might be not understand, or vice versa. It makes writing is very complex so it needs a careful efforts to produce it.

One of the most esential issues in writing is feedback. According to Asiri (1996), feedback is helpful in encouraging students not to consider what they have written as a final product and in helping them to write multiple drafts and to revise their writing several times, in order to produce a much improved piece of writing. From the given feedback, the students are expected to learn or to make reflection so, the same errors will not occur anymore. Furthermore, Kroll (2003) notes, "second language writers often benefit most and make the most progress when teachers contribute to this goal through a variety of intervention strategies available in classroom settings". One of these intervention strategies provides feedback to students' writing, the common practice - the written feedback. Furthermore, throughout the different stages of writing, giving feedback is essential in order to help students improve their writing piece (Ismail, Maulan \& Hasan, 2008).

The next problem arises in the method of giving feedback so, it is effective. According to Shirzad, Nejadansari, and Shirzad (2015), providing feedback to students' writing errors has always been one of the teachers' difficult tasks. Feedback given must be appropriate to the target. It means that the method suitable for students' need. Some of the students feel direct feedback good for them, but the rest might like indirect feedback. In addition, certain students might be uncomfortable on the feedback. They were down when the errors were shown to them. As the consequence, they became reluctant to write.

In relation to writing nature covering both cognitive and linguistics aspects, giving good proportion of feedback to them. According to Jamalinesari, Rahimi, Gowhary, and Azizifar (2015). Though L2 writing teachers were aware of students' perceptions of written 
feedback and most tried to give helpful feedback to their students, teachers might not be fully aware of how much feedback they gave locally (i.e., spelling, grammar, and punctuation) and global (i.e., ideas, content, and organization) issues nor whether the type of feedback they feel they should give adheres to their beliefs about written feedback. It makes the giging of feedback should be done in deep consideration.

In reality, direct feedback is mostly applied by the teachers. In addition, local aspect is mostly corrected. Direct or explicit feedback occurs when the teacher recognizes an error and offers the correct form (Jamalinesari, Rahimi, Gowhary, and Azizifar, 2015). Furthermore, in the case of direct corrective feedback the teacher gives the correct form to the students, and it is desirable for low-level-of-proficiency students who are unable to self-correct and do not know what the correct form might be (Eslami, 2014). However, it requires minimal processing on the part of the learners and thus, it may not contribute to longterm learning (Ellis, 2009).

The phenomenon of using direct feedback was found in STKIP Suar Bangli. All lecturers teaching Writing I, II, and III courses used this type of feedback to correct students' writing. In addition, focus of the feedback is mostly on local aspect of writing, such as: grammatical structure, mechanics, and vocabulary. The lecturers used to give scratches on the errors made by the students. In addition, the correct form is also provided. In fact, the students' writing skill is still low. It arises to investigate how actually the impact of direct feedback on writing.

\section{Methods}

This research was done in the fourth semester of English education department in STKIP Suar Bangli. There were three students who took Writing III course. In this course, the students were expected to write short essay (consisting of 5-7 paragraphs). For one essay, the students were given one week to finish it. Here, two genres became the focused research, descriptive and report. After the students collected their writing, the lecturer gave correction or feedback on the writing. The assessment focused on five elements, namely: content and development, organization, grammar, vocabulary and mechanics. Then, it was returned so they knew their mistakes. After that, they had to write new writing. This new writing was analyzed to know the effectiveness of correction and feedback given by lecturer. The analysis was done by qualitative method analysis.

\section{Finding}

\section{Finding and Discussion}

The data analysis results were divided into two, error made before and after correction. They can be presented in the Table 1 and Table 2 .

Table 1: List of Students' Error before Direct Correction

\begin{tabular}{cccccc}
\hline & Content & Organization & Grammar & Vocabulary & Mechanics \\
\hline Subject 1 & 5 & 8 & 12 & 5 & 8 \\
Subject 2 & 6 & 7 & 17 & 6 & 12 \\
Subject 3 & 4 & 5 & 14 & 6 & 12 \\
Total & 15 & 20 & 43 & 17 & 32 \\
\hline
\end{tabular}

Based on the Table 1, it was known that the most mistake made by the students was grammar. It was followed by mechanics, organization, vocabulary, and content. In terms of 
grammar, the students did not fully understand about how to use correct tense, verb agreement, to infinitive, and gerund. Furthermore in mechanics, the students made many errors on the use of punctuation marks (colon and semicolon) and capital letter (quotation and place name). The students also could not organize their ideas chronologically. It seemed that their ideas jumped up, which should be first and next were not good yet. So, their ideas did not flow smootly. In content, most of them had written their ideas well. However, the topic sentence or thesis statement was not more deeply and critically. Sometimes, it was found irrelevant ideas appeared.

Then, direct feedback or correction was done on the errors. Here, the errors were given scratch, then the correct revision was given. For example, the students made " they did not grew...", then the revision "they did not grow...". There was no reason given why the answer was that. After feedback was given, the result of error can be presented in Table 2.

Table 2: List of Students' Error after Direct Correction

\begin{tabular}{lccccc}
\hline & Content & Organization & Grammar & Vocabulary & Mechanics \\
\hline Subject 1 & 4 & 8 & 12 & 5 & 8 \\
Subject 2 & 5 & 6 & 16 & 5 & 10 \\
Subject 3 & 4 & 4 & 12 & 6 & 11 \\
Total & 13 & 18 & 40 & 16 & 29 \\
\hline
\end{tabular}

After the direct correction was given, it was known that the number of errors reduced. However, the improvement was less significant. Here, grammar is still the most frequent error occured. By comparing the Table 1 and Table 2, it can be known that error in content reduces 2 ; organization reduces 2 ; grammar reduces 3 ; vocabulary reduces 1 ; mechanic reduces 3 . It indicates that the application of direct feedback is less effective in improving the EFL writing quality.

\section{Discussion}

By seeing the result, less improvement occured in writing quality. The students still made same errors types as before direct feedback was given. For example, it was still found mistakes relating to simple past tense pattern and the addition of ' $\mathrm{s}$ ' and 'es' for the third singular subject in simple present tense. It indicates that the feedback given was less concerned by the students. In other words, they did not learn more deeply on the errors. Their concern was on the error they made on their writing. There was no futher learning about the made errors.

It seemed that there were four main things why the direct feedback were less effective on writing. This is drawn based on the observation and deep interview. First, there is no discovery learning process on it. Second, It does not direct to reflective learning. Third, the students' point of view regrading that feedback is an end of learning. Fourth, the students are less motivated to learn more deeply about their errors.

When direct feedback was applied, the teacher provided marks the errors and also the target form (Van Beuningen, De Jong \& Kuiken, 2008). It means that the students had been provided the correct answers or revisions. The students just received the correct forms/answers without searching the reasons. It means that there was no discovery process. As the consequence, the students were not trained to find something or to think critically. As being known that critical thinking is really needed to develop, organize, and transform ideas into correct grammar.

Direct feedback also did not create reflective learning. The students would not make reflection why they should write or make it. Based on the small interview with all subjects, 
after direct feedback was given, they have never reflected on their works. They did not think too much on the feedback. In writing the new works, they also did not reflect on the previous feedback. Since reflection was never done, there might not be learning process for their further writings. As the result, the students still make same errors as before.

From the students' perspective, feedback was considered as an end of their writing. All subjects did not think that feedback was given to make them better writing. However, they just regarded the feedback was the final result which do not have contribution in the future. Exploration on the errors is rarely done by the students. Here, they can explore information in the internet, books, or journal to investigate the correction given.

Lastly, less motivation is owned by the student to learn more deeply about the errors. All subjects said that they were not motivated to find out how and why the errors occured. When feedback was given, the students feel it was a common without any efforts to improve it. They were reluctantly to explore deeply about their errors by searching sources.

\section{Conclusion}

The data analysis shows that direct feedback is less effective in improving the students' writing quality. The students still make the same mistakes as before. Four factors are identified as the factor causing it. Those factors are both from the learning condition created by direct feedback and the students themselves. It seems that the direct feedback given is a little bit useless for the students. Even though feedback signs the students error and revision, but it can not be maximized by the students. The students do not learn from the feedback.

By seeing the research results, three suggestions can be drawn. First, the use of direct feedback should be reduced in writing since it can not give significant effect. Several alternative options can be tried, such as: indirect feedback, self-assessment, and peer assessment. Second, If direct feedback is still used, the lecturer should motivate the students by explaining the importance of the feedback. Then, follow up activities must also be told so the feedback can be maximized by the students. Third, there should be a further researches which investigate deep factors causing direct feedback has insignificant effect on students' writing skill.

\section{References}

Asiri, I. (1996). University EFL Teachers' Written Feedback on Compositions and Students' Reactions. Ph.D. Dissertation. University of Essex.

Boric, G.D. (2007).Effective teaching methods: Research-based practice. New Jersey: Pearson Merril Prentice Hall.

Ellis, R. (2009). A typology of written corrective feedback types. ELT Journal, Volume 63 97-107.

Eslami, Elham. (2014). The Effects of Direct and Indirect Corrective Feedback Techniques on EFL Students' Writing. Procedia - Social and Behavioral Sciences. 98, 445 - 452. Available online at www.sciencedirect.com

Jamalinesari, Ali., Rahimi, Farahnaz., Gowhary, Hsbib, and Azizifar, Akbar. (2015). The Effects of Teacher-Written Direct vs. Indirect Feedback on Students' Writing. Procedia - Social and Behavioral Sciences. 192, $116-123$

Kroll, B., (2003), Considerations for Teaching an ESL/EFL Writing Course, in M.Celce Murcia (Ed.), Teaching English as a Second or Foreign Language (3rd ed.), 219-232 Heinle and Heinle, Boston MA.

Shirzad, Maryam., Nejadansari, Dariush and Shirzad, Hedayatollah. (2015). The Effects of Teacher, Guided, and Self Error Correction on Iranian EFL Learners' L2 Writing 
Accuracy. Journal of Applied Linguistics and Language Research. 5, 35-47. Available online at www.jallr.ir

Van Beuningen, C. G., De Jong, N. H., \& Kuiken, F. (2008). The effect of direct and indirect corrective feedback on L2 learners' written accuracy. ITL International Journal of Applied Linguistics, 156, 279-296. 